\title{
Development of Multiliteration and Higher Order Thinking Skills Through Integrated Learning
}

\author{
Kurniasih \\ Indonesian Education University, Bandung, Indonesia \\ e-mail: kurniasihts@gmail.com
}

\begin{abstract}
This paper aims to describe integrated learning as a learning approach, which is suggested to be applied in order to develop multiliteration and higher order thinking skills. Multiliteration and higher order thinking skills are needed and must be mastered by the community so that they can actively participate in the $21 \mathrm{st}$ century civilization. In this context, education or in its operation is learning to be challenged to be able to develop skills. Based on the literature study, it was concluded that to develop multiliteration and higher order thinking skills, one approach that needs to be applied is the integrated learning approach. There are two things that need to be considered in the application of integrated learning. First, the teacher should formulate learning objectives to develop cognitive process skills at levels C2 through C6. Second, in implementing integrated learning, the teacher ideally applies learning models such as: discover, inquiry, problem based learning, project based learning, cooperative learning models, etc.
\end{abstract}

Keywords: Multiliteration, higher order thinking skills, integrated learning.

\section{Introduction}

Multiliteration and Higher Order Thinking Skills (HOTS) are capabilities that people need to be able to live and actively participate in the information age in the 21 st century society. 21 st century civilization known as the information era was triggered by the rapid development of information technology and science. This era challenges every member of the community to continually learn to improve their abilities, so they can adapt to the times with a variety of new problems that arise and must be solved.

In Indonesia, the multiliteration and HOTS capabilities of the community are still low. The INAP (Indonesia National Assessment Program) test results show: (1) Ability to read, which is in the poor category of $46.83 \%$, in the adequate category of $47.11 \%$ and the good category is only $6.06 \%$; (2) Mathematics, which is categorized as less by $77 \%$, sufficient category, which is $20.50 \%$ and good category is only $2.29 \%$; (3) Science, which is categorized as less than $73.61 \%$, enough category is $25.38 \%$ and good category is only $0.01 \%$ (Puspendik, Balitbang, Kemdikbud, 20019).

The results of the INAP test above have become a challenge for the world of education in Indonesia. Education as an effort to facilitate students to develop their full potential optimally needs to be carefully planned. The problem is, what kind of learning needs to be implemented to develop multiliteration skills and HOTS learners? These questions can be answered by first examining what is meant by multiliteration, the types of literacy, the understanding of HOTS, the types of thinking that include HOTS, and 
the implications for learning so that it has the function of developing multiliteration and HOTS.

\subsection{Multiliteracy}

The concept of multiliteration developed from the concept of literacy, in accordance with the challenges and needs of society, so in the 21 st century the concept of muliterasi developed. Initially literacy contained a narrow meaning, namely as the ability to read and write (Sulzvy in Hartati, 2016). In a broad sense, literacy does not only include the ability to read and write, but also includes communication skills, meaning practices related to knowledge, language and culture. In line with this concept, the Education Development Center explains that literacy is the ability of individuals to use all their potential and skills possessed in their lives (Mayuni, 2017).

According to Abidin (2015) there have been five stages of the development of the meaning of literacy. At the first stage of development, literacy is defined as the ability to use language and images in a rich and varied form to read, write, listen, speak, see, present, and think critically about ideas. In the second stage, literacy is closely related to social situations and practices. Literacy is seen as a social and cultural practice rather than being seen as a contingent free cognitive achievement. In the third stage, the meaning of literacy was expanded by the use of information technology and multimedia development. In the fourth stage, critical literacy develops. In the fifth stage, in line with the development of information and communication technology, the meaning of literacy developed into multiliteration.

Multiliteration is: 1) Multicontext, meaning it covers various contexts of situations and various scientific contexts. 2) Multi media, meaning that multiliteration is related to the use of various media, including conventional media and digital media. 3. Multiculturalism, meaning that the text is not culturally neutral, but is always motivated by the author's culture. Therefore, anyone ideally must be able to criticize the contents of the text (critical literacy).

\subsection{Higher Order Thinking Skills (HOTS)}

Multiliteration and 21 st century skills have implications so that each individual has a higher order thinking skills. In order to master and apply these skills, certainly cognitive process skills that are classified as higher order thinking skills are needed.

Ideally, cognitive process skills that are classified as higher order thinking skills are formulated in educational or learning goals. Given the importance of this, the category categories in cognitive processes have been structured in a taxonomy of educational objectives. This was originally compiled by Bloom in 1956, then revised by Anderson et al in 2001 (Anderson, et al, 2001).

As Anderson et al (2001) stated, the structure of cognitive process categories is as described in the figure below: 


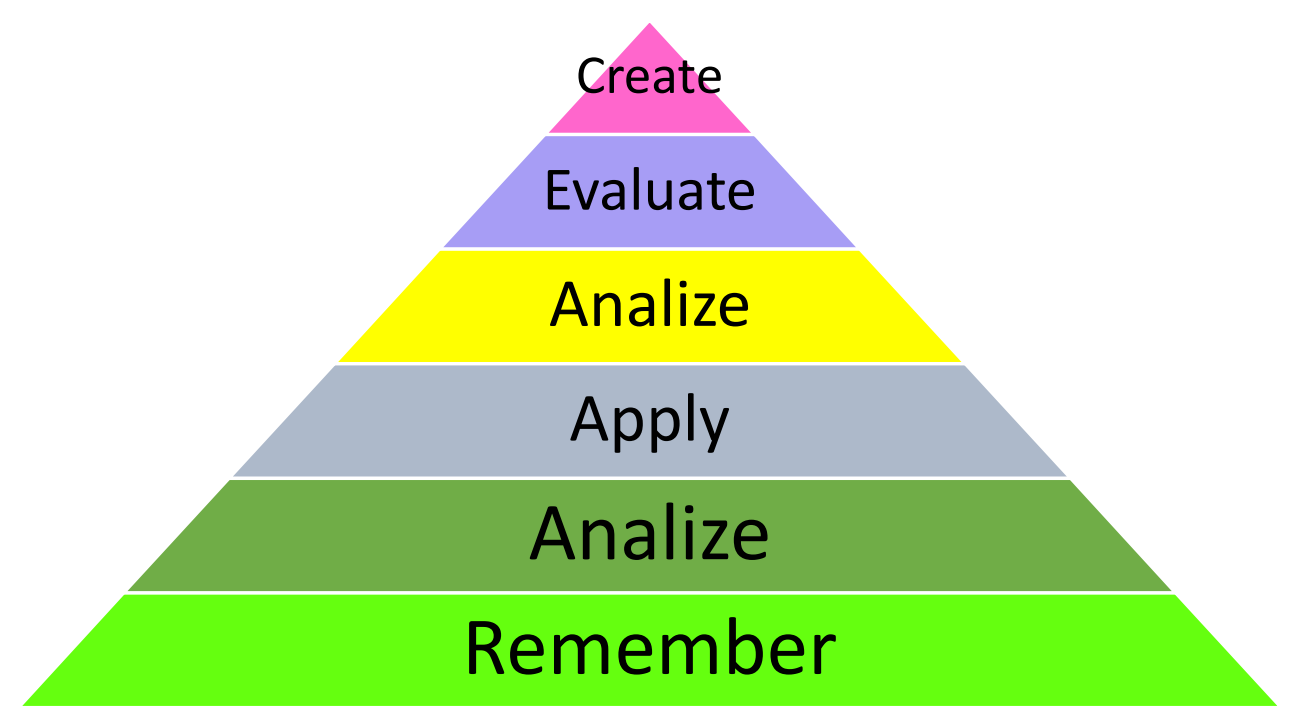

Figure 1. The Structure of the Cognitive Process Category

Regarding the structure of the cognitive process category above, remember is known as level $\mathrm{C} 1$, understand as level $\mathrm{C} 2$, apply as $\mathrm{C} 3$, analyse as level $\mathrm{C} 4$, evaluate as level $\mathrm{C} 5$, and create as level C6. Each category of cognitive processes consists of two or more cognitive processes that are more specific, so that they all amount to 19. All of these are further described by Anderson et al in the form of verbs. Furthermore, based on the level of cognitive processes, education experts classify categories of cognitive processes into two groups. $\mathrm{C} 1$ is classified as low order thinking skills (LOTS), while C2 to C6 are grouped as higher order thinking skills (HOTS).

\subsection{Development of Multi Literacy and HOTS Through Integrated Learning}

In 2003 based on the results of his meeting in Prague, the United Nations indicated the importance of literacy for the citizens of the world. The literacy components suggested by the UN to be controlled by the citizens of the world are: 1) Basic Literacy, 2) Library Literacy, 3) Technology Literacy, 4) Media Literacy, and 5) Visual Literacy. Looks at the above statement, the importance of multi literacy for the citizens of the world, and as explained that multi-literacy requires higher order thinking skills. In this regard, in the context of education in Indonesia, the Ministry of Education and Culture of the Republic of Indonesia considers it important to implement the National Literacy Movement (GLN). In this context Mayuni (2017) suggests that there are six basic literacies developed, namely:

\subsubsection{Language and Literature Literacy}

Language literacy is the ability to read and write. Literacy / literacy qualities or abilities which include the ability to read and write. The ability to process and understand information while carrying out the process of reading and writing.

\subsubsection{Numeration Literacy}

Numeracy ability is the ability to solve problems, explain processes and analyze information related to numeration. People are called numeracy literates if: 
a. know the basics of addition, subtraction, multiplication and division;

b. can use numeration confidently and effectively;

c. can understand how to transfer the skills they have to solve problems.

\subsubsection{Science Literacy}

Science Literacy is the ability to use science knowledge, identify questions, draw conclusions to understand and make decisions regarding nature. Someone is called literate to science, if they have competence:

a. explain the phenomenon of science;

b. evaluating and designing science knowledge and skills independently;

c. interpret scientific data and evidence.

\subsubsection{Digital Literacy}

Digital Literacy is the ability to use digital media, communication tools or networks to find, evaluate, use, make information and use wisely. Its features include: computer basics, internet usage and productive programs, security and confidentiality and digital lifestyle.

\subsubsection{Financial literacy}

Financial Literacy is the ability to understand how money affects the world (how one manages to make money, manage money, invest money and contribute money to help others). This capability is a series of processes or activities to improve the knowledge, beliefs, and skills of consumers and society so that they are able to manage finances well.

\subsubsection{Cultural literacy and citizenship}

Cultural literacy and citizenship is the ability to understand, appreciate and participate proficiently in culture. The ability to actively participate and initiate change in the community and the larger social environment.

To realize the hope that multiliteration and higher order thinking skills are owned by students, integrated learning is one solution to be applied. As stated by Wolfinger (in Hernawan, et al., 2007) the rational importance of integrated curriculum and integrated learning are as follows:

1. Most problems and experiences (including learning experiences) are interdisciplinary, so to understand, learn, and solve them multi-skills are needed.

2. There is a high demand for collaborative interaction in solving various problems.

3. Make it easy for children to make connections between schemata and transfer of understanding between contexts.

4. For efficiency.

5. There is a high demand for children's involvement in the learning process.

Integrated learning has advantages, including: 1) integrated learning can develop students' thinking skills, especially with regard to HOTS. But in this case the role of the teacher is seen as important for formulating learning objectives regarding HOTS. 2) presenting contextual activities in accordance with the problems often encountered by students in their environment, so students will be trained to do problem solving and apply other cognitive process categories (C2 sd, C6). 
In general, integrated learning has similarities with non-integrated learning. The difference is that integrated learning packaging material teaching is not based on the structure of a scientific discipline or certain subjects, but is packaged in crossdisciplinary disciplines or subjects combined by a particular focus or theme (Kurniawan, 2011).

As stated in the Minister of Education and Culture Regulation No. 22 of 2016 concerning Learning Implementation that Core Activities in learning should apply integrated thematic approaches and scientific approaches. In connection with that, the suggested learning model is applied to the discovery model, inquiry, problem based learning, project based learning, and cooperative learning models. From the description above it can be understood that integrated learning is one of the learning that is deemed appropriate to be applied to develop multiliteration and higher order thinking skills.

\section{Conclusion}

Multiliteration and Higher Order Thinking Skills (HOTS) are capabilities that people need to be able to live and participate actively in the information age in 21 st century society. Descriptions of INAP test results about the level of literacy skills and the level of Indonesian people's thinking abilities that have been expressed by the Republic of Indonesia Ministry of Education and Culture Indonesia, then education or learning to develop multiliteration and Higher order thinking skills are seen as important.

Based on the literature review as explained in the discussion, it is understood that to develop multiliteration and higher order thinking skills, integrated learning is one of the learning approaches suggested to be applied. As for its operations, the integrated learning needs to be supplemented by applying discovery learning models, inquiry, problem based learning, project based learning, and cooperative models.

\section{Bibliography}

[1] Abidin, Y. (2015). Pembelajaran Multiliterasi: Sebuah Jawaban atas Tantangan Pendidikan Abad 21 dalam Konteks Keindonesiaan. Bandung. PT. Refika Aditama.

[2] Anderson, L. W. et al (Ed.). (2001). A Taxonomy for Learning, Teaching, and Assesing: Revision of Bloom's Taxonomy of Educational Objective. New York. Addison Wesley Longman Inc.

[3] Hartati, T. (2016). Laporan Penelitian Fundamental: Optimalisi Manajemen Berbasis Sekolah Dasar (MBS) untuk Membangun Kelas Literasi dan Kemampuan Multiliterasi Siswa Sekolah Dasar. Bandung. UPI.

[4] Hernawan, A. H, et al. (2007). Pembelajaran Terpadu di Sekolah Dasar. Jakarta. Universitas Terbuka.

[5] Mayuni, I. (2017). Pengantar Diskusi Penyusunan Pedoman dan Materi Gerakan Literasi Nasional untuk Guru. Jakarta. Badan Pengembangan dan Pembinaan Bahasa - Kementerian Pendidikan dan Kebudayaan Republik Indonesia.

[6] Kurniawan, D. (2011). Pembelajaran Terpadu: Teori, Praktik dan Penilaian. Bandung. Pustaka Cendekia Utama. 
[7] Peraturan Menteri Pendidikan dan Kebudayaan Nomor 20 Tahun 2016 Tentang Proses Pembelajaran.

[8] Puspendik, Kemdikbud (2019), Hasil Indonesian National Assesment Programme (INAP). 